\title{
Growth Performance and Bio-Economic Indices of Varying Mixtures of Grass-Legume Pellets Fed to West African Dwarf (Wad) Goats
}

\author{
Sunday Oyewole* and Olusola Aderinola \\ Department of Animal Production and Health, Ladoke Akintola University of Technology, P. M. B. 4000, \\ Ogbomoso, Oyo State, Nigeria. \\ *Email of the corresponding author: tpoyewole@gmail.com
}

\begin{abstract}
The need to improve forage conservation for animal usage during the dry season is a necessity. Varied mixture of grass-legume pellets (60\% Panicum maximum (6Pm); 30\% Panicum maximum + 30\% Lablab purpureus (3Pm3Lp); 40\% Panicum maximum $+20 \%$ Lablab purpureus (4Pm2Lp); 40\% Panicum maximum $+20 \%$ Stylosanthes hamata (4Pm2Sh) and 30\% Panicum maximum $+30 \%$ Stylosanthes hamata (3Pm3Sh)) were used to assess growth performance and bio-economic indices of varied mixtures of grass-legume pellets fed to West African Dwarf (WAD) goats. Thirty (30) WAD goats (aged 6-7 months) were used and the experimental design was a Completely Randomized Design. Data obtained were crude protein, crude fibre, ash, minerals, dry matter intake (DMI), crude protein intake (CPI), protein efficiency ratio (PER), cost of feed/weight gain (CF/W) and analyzed by one way ANOVA. 3Pm3Sh pellets had the highest $(\mathrm{p}<0.05) \mathrm{CP}(17.32 \%)$ while $6 \mathrm{Pm}$ had the highest $(p<0.05)$ values of fibre fractions except for hemicellulose. There was no significant influence on the mineral contents except for iron, copper and chlorine. WAD goats fed $3 \mathrm{Pm} 3 \mathrm{Sh}$ had the highest $(\mathrm{p}<0.05)$ DMI (458.72g/animal/day), CPI (76.72g/animal/day) and PER (0.91) which resulted in highest $(\mathrm{p}<0.05)$ weight gain $(3.82 \mathrm{~kg})$. The cost of feed/weight gain was similar across the pellets except for 3Pm3Lp. Higher $(\mathrm{p}<0.05) \mathrm{CF} / \mathrm{W}$ was recorded for $3 \mathrm{Pm} 3 \mathrm{Lp}$. The study concluded that the grass-legume pellets can be employed as ruminant feed while pellet of $3 \mathrm{Pm} 3 \mathrm{Sh}$ is the best grass-legume combination for WAD goats. Thus, this pellet can be fed to WAD goats during the dry season.
\end{abstract}

Keywords: WAD goats, pellet, Panicm maximum, Lablab purpureum, Stylosanthes hamata

DOI: $10.7176 / \mathrm{JBAH} / 9-24-09$

Publication date: December $31^{\text {st }} 2019$

\section{Introduction}

Pasture forage being a means of ruminant animal feeding in the tropics, are of low crude protein and dry matter yield especially in the dry season (Aderinola et al., 2011). This has led to a rational need for conservation forages through hay and silage but which did not eventually meet the nutritional demands of the ruminant. Hence, need to develop a homogenous feed - forage pellet becomes a necessity. Goats play a significant role in the food chain and overall livelihoods of rural households (Lebbie, 2004). In South-West Nigeria, they are used for customary rites in addition to meat production and religious purposes (Odeyinka and Okunade, 2005). The animals thrive well on pasture, which is a major agricultural feed resource that generally supports both intensive and extensive systems of ruminant production (Aderinola et al., 2008), even though they can also survive on household wastes and crop residues (Odeyinka, 2000). National Research Council (1995) reported that the protein content of most grasses for ruminants in the tropics is within the range of $11-14 \%$ of the dry matter and this is sufficient for modest livestock productivity. However, in the dry season, this usually falls below the critical level of $7 \%$ required for microbial activities in the rumen (Agricultural Research Council, 1980) thus, aggravated cost of supplemental feeds (Okoruwa and Adewumi, 2010). Effective management of available forage and by-products could strategically be exploited to ameliorate scarcity in the dry season (Ajayi, 2008). A typified means is pelletizing forages alongside other available nutritional by-products as complete diets for ruminant in the dry season. Feed pelleting has numerous benefits such as preservation of feed for a longer period, holding the feed together better during handling, increasing bulk density and improving palatability thereby enhancing its intake by animals (Baudon and Hancock, 2003; Fasae, 2014). It also reduces dustiness and wastage of feed as well as the cost of feeding hence increasing livestock production (Conrad, 1966; Amole et al., 2012; Singh et al., 2016). This processing method if well engaged could be exploited to augment feed supply to West African Dwarf goat. Hence, this paper aimed at evaluating the growth performance and bio-economic indices of varying mixtures of grasslegume pellets fed to West African Dwarf (WAD) goats. 


\section{Materials and Methods}

\subsection{Experimental Site}

The experiment was carried out at the Sheep and Goat Unit of the Teaching and Research Farm, Ladoke Akintola University of Technology (LAUTECH), Ogbomoso. The area is located at Latitude 80N, Longitude 40E with an annual rainfall of 1270 to $2030 \mathrm{~mm}$, which occurs in 7-10 months with a peak between July and September of the year. The range of temperature of the area is between $280 \mathrm{C}$ to $330 \mathrm{C}$, while the humidity is about $74 \%$ all year round except for January when the dry wind blows from the North (Olaniyi, 2006).

\subsection{Procurement and Processing of Experimental Feedstuffs}

Forage (Stylosanthes hamata and Lablab purpureum) were harvested at 8-week of age. They were air-dried to a constant weight and bagged in air-tight jute sac until use. Cassava peels were sourced at gari processing units in Ogbomoso. Brewer's Dried Grain (BDG) and salt were sourced from a reputable commercial feed store and the open market respectively within Ogbomoso. Before the commencement of feeding regime, the feed materials sourced for and the air-dried forages were formulated in proportion to experimental diet composition to ensure forage-based pellets with $60 \%$ forage composition, where all the ingredients were milled and mixed with water (at $100 \mathrm{ml}$ per $\mathrm{kg}$ ) to aid the binding process. Thereafter, it was subjected to pelleting using $6 \mathrm{~mm}$ mesh size to produce pelleted forage of average length of $40 \mathrm{~mm}$. The pellets were sun-dried for three days to avoid spoilage.

\subsection{Experimental pellets preparation}

Five experimental diets were formulated such that each pellet contains $60 \%$ of forage at varied mixtures: Diet $1=$ Panicum maximum (60\%); Diet $2=30 \%$ Panicum maximum $+30 \%$ Lablab purpureus (3Pm3Lp); Diet $3=40 \%$ Panicum maximum $+30 \%$ Lablab purpureus (4Pm2Lp); Diet $3=40 \%$ Panicum maximum $+20 \%$ Lablab purpureus (4Pm3Lp); Diet $4=40 \%$ Panicum maximum $+20 \%$ Stylosanthes hamata (4Pm2Sh); Diet $5=30 \%$ Panicum maximum $+30 \%$ Stylosanthes hamate (3Pm3Sh) with fixed inclusion of $21 \% \mathrm{BDG}, 16 \%$ cassava peel, $2 \%$ local potash, $1 \%$ salt

\subsection{Animals, Experimental Design and Management}

Thirty (30) growing West African Dwarf goats were subjected to growth trial on various mixtures of grass-legume pellets. The animals of initial live-weights of $7.57 \pm 0.11$ were purchased from small ruminant markets in Ogbomoso and neck-tagged for proper identification. The goats were quarantined for three weeks before the commencement of the study. During this period, oxytetracycline and a multivitamin preparation were administered at the rate of $1 \mathrm{ml}$ per $10 \mathrm{~kg}$ bodyweight through intramuscular route for prophylactic treatment. Ivermectin was also administered subcutaneously at the rate of $0.2 \mathrm{ml}$ per $10 \mathrm{~kg}$ bodyweight against external and internal parasites. The goat pens were thoroughly washed and disinfected. The animals were grouped and fed ad-lib fresh P. maximum daily. After the quarantine period, the animals were balanced for weight and randomly grouped into five treatments of six goats per treatment. The animals were thereafter moved into wooden pens measuring $1.20 \mathrm{~m} 2$ $(1.5$ by $0.8 \mathrm{~m})$ and equipped with feeding and watering facilities, they were fed the five treatments using a completely randomized design (CRD).

\subsection{Data Collection}

Five hundred grams representative samples from the freshly produced experimental pellets were oven-dried to constant weight and taken to the laboratory for determination of the chemical and mineral components. Dry matter and nutrient intakes from the feed offered were computed from the daily total intakes by deducting the quantity of the feed refused from the quantity offered. Animals were weighed at the commencement of the experiment and subsequently every week using a hanging scale, before serving the animals.

\subsection{Chemical Analysis}

Pellet samples from the various grass-legume mixtures were ground in a Wiley mill to pass through $1.0 \mathrm{~mm}$ sieve screen. Thereafter, the following chemical analyses were carried out in the laboratory: Proximate composition was determined according to AOAC (2000). Fibre fraction: Neutral Detergent Fibre (NDF), Acid Detergent Fibre (ADF) and Acid Detergent Lignin (ADL) were determined using the method of Van Soest et al. (1991). Cellulose was estimated as the difference between ADF and ADL while hemicellulose was estimated as the difference between NDF and ADF. Mineral determination of both macro and micro minerals were carried out with atomic absorption spectrophotometer (Fritz and Schenk, 1979). 


\subsection{Statistical Analysis}

Weight and feed intake data were subjected to one-way analysis of variance in a completely randomized design using the SPSS (2010). When the analysis of variance indicated the existence of significant differences among treatment means, Duncan's multiple range test (DMRT) of the same package was employed to test and locate the treatment means that significantly differed from the rest.

\section{Results and Discussion}

\subsection{Results}

The chemical compositions (\%) of the experimental pellets made from varying mixtures of grass-legume forage were presented in Table 1. There was significant $(\mathrm{p}<0.05)$ variations across the treatments except for DM, EE and ash content. Crude protein was highest for 3Pm3Sh (17.32\%), although similar to 4Pm2Lp (17.10\%) while other treatments were lower but similar to one another. Nitrogen free extract and hemicellulose had similar trend while neutral detergent fibre, acid detergent fibre and cellulose followed the same trend except for ADL for 4Pm2Lp that showed a lower value $(11.87 \%)$. Panicum maximum $(6 \mathrm{Pm})-$ based pellet had lower contents of NFE and hemicellulose as compare to varied grass-legume pellets. In contrast, 6Pm had higher NDF, ADF, ADL and cellulose values relative to other treatments.

Table1. Chemical composition $(\%)$ of the experimental pellets made from varying mixtures of grass-legume

\begin{tabular}{|c|c|c|c|c|c|c|}
\hline Parameters & 6Pm & 3Pm3Lp & 4Pm2Lp & 4Pm2Sh & 3Pm3Sh & $\operatorname{SEM}( \pm)$ \\
\hline Dry Matter & 93.13 & 93.22 & 94.10 & 93.05 & 94.04 & 1.12 \\
\hline Crude Protein & $16.62^{\mathrm{b}}$ & $16.84^{b}$ & $17.10^{\mathrm{a}}$ & $16.93^{b}$ & $17.32^{\mathrm{a}}$ & 1.04 \\
\hline Ether extract & 3.56 & 3.52 & 3.65 & 3.63 & 3.63 & 0.21 \\
\hline Crude fibre & $29.77^{\mathrm{a}}$ & $20.32^{b}$ & $20.84^{b}$ & $21.16^{\mathrm{b}}$ & $21.32^{\mathrm{b}}$ & 2.15 \\
\hline Ash & 7.13 & 7.36 & 7.40 & 7.34 & 7.43 & 0.25 \\
\hline NFE & $36.05^{\mathrm{b}}$ & $45.28^{\mathrm{a}}$ & $45.09^{\mathrm{a}}$ & $44.17^{\mathrm{a}}$ & $44.32^{\mathrm{a}}$ & 2.21 \\
\hline NDF & $58.81^{\mathrm{a}}$ & $51.31^{\mathrm{b}}$ & $50.97^{b}$ & $51.45^{\mathrm{b}}$ & $51.66^{\mathrm{b}}$ & 1.23 \\
\hline $\mathrm{ADF}$ & $45.46^{\mathrm{a}}$ & $42.14^{b}$ & $41.26^{\mathrm{b}}$ & $42.33^{\mathrm{b}}$ & $42.51^{b}$ & 1.43 \\
\hline $\mathrm{ADL}$ & $13.39^{\mathrm{a}}$ & $12.15^{\mathrm{b}}$ & $11.87^{\mathrm{c}}$ & $12.41^{b}$ & $12.60^{\mathrm{b}}$ & 0.43 \\
\hline Cellulose & $32.07^{\mathrm{a}}$ & $30.27^{b}$ & $29.39^{b}$ & $29.92^{b}$ & $29.91^{\mathrm{b}}$ & 0.54 \\
\hline Hemicellulose & $13.35^{\mathrm{b}}$ & $9.17^{\mathrm{a}}$ & $9.71^{\mathrm{a}}$ & $9.12^{\mathrm{a}}$ & $9.15^{\mathrm{a}}$ & 0.53 \\
\hline
\end{tabular}

a,b,c: Means carrying different superscript in each row are significantly different $(\mathrm{p}<0.05)$; SEM: standard error of mean; 6Pm: 60\% P. maximum; 3Pm3Lp: 30\% P. maximum $+30 \%$ L. purpureus; 4Pm2Lp: 40\% P. maximum + $20 \%$ L. purpureus; $4 \mathrm{Pm} 2 \mathrm{Sh}: 40 \%$ P. maximum $+20 \%$ S. hamata; $3 \mathrm{Pm} 3 \mathrm{Sh}: 30 \%$ P. maximum $+30 \%$ S. hamata

There was no significant influence on the mineral contents of the experimental pellets made from varying mixtures of grass-legume forage except for iron, copper and chlorine (Table 2). Pellet from 3Pm3Sh had highest $(\mathrm{p}<0.05)$ iron $(18.48 \mathrm{mg} / \mathrm{kg})$, copper $(0.86 \mathrm{mg} / \mathrm{kg})$ and chlorine $(190.78 \mathrm{mg} / \mathrm{kg})$ whereas $6 \mathrm{Pm}$ and $4 \mathrm{Pm} 2 \mathrm{Lp}$ had least values (Iron: 17.27 and 17.47; Copper: 0.60 and $0.65 \mathrm{mg} / \mathrm{kg}$ ) while chlorine content $(\mathrm{mg} / \mathrm{kg})$ was least $(\mathrm{p}<0.05)$ for $6 \mathrm{Pm}$.

Table3 reveals nutrient intake of West African Dwarf goat fed on varied grass-legume mixture pellets. Animals on 3Pm3Sh pellets had highest DMI, CPI, CFI and ash intake (g/animal/day) except for DMI (\% of BW). Animals on 3Pm3Lp had highest DMI (of \% BW) while 6Pm, 4Pm2Sh and 3Pm3Sh were similar but least DMI (\% of BW).

Growth indices of West African Dwarf goat fed on varied grass-legume mixture pellets were significant $(p<0.05)$ are as revealed in Table 4. Animals fed of 4Pm2Lp, 4Pm2Pm2Sh and 3Pm3Sh had highest final weight (11.08, 11.15 and $11.39 \mathrm{~kg}$ ) respectively while least values $(10.74$ and $10.44 \mathrm{~kg}$ ) were recorded for animals on $6 \mathrm{Pm}$ and 3Pm3Lp. Total weight gain $(\mathrm{kg})$, ADG (g/animal/day) and TFI $(\mathrm{kgDM} /$ animal were recorded for animals on 3Pm3Sh (3.82, 68.20 and 25.69 respectively). FCR was least for animals on 4Pm2Lp (6.79), 4Pm2Sh (6.47) and 3Pm3Sh (6.73) while 3Pm3Lp had highest (8.41) but similar to 6Pm (7.13). However, the highest protein efficiency ratio (PER) was recorded for 3Pm3Sh (0.91) while the least value (0.71) was observed for 3Pm3Lp. 


\begin{tabular}{lllllll}
\multicolumn{6}{l}{ Table2. Mineral content of the experimental pellets made from varying mixtures of grass-legume forage } \\
\hline Parameters & 6Pm & 3Pm3Lp & 4Pm2Lp & 4Pm2Sh & 3Pm3Sh & SEM( \pm ) \\
\hline Sodium (\%) & 0.12 & 0.13 & 0.12 & 0.14 & 0.14 & 0.01 \\
Calcium (\%) & 0.26 & 0.27 & 0.26 & 0.28 & 0.29 & 0.03 \\
Potassium (\%) & 2.66 & 2.68 & 2.67 & 2.69 & 2.70 & 0.14 \\
Magnesium (\%) & 0.44 & 0.46 & 0.44 & 0.47 & 0.48 & 0.03 \\
Phosphorus (\%) & 0.36 & 0.38 & 0.37 & 0.39 & 0.40 & 0.04 \\
Iron (mg/kg) & $17.27^{\mathrm{c}}$ & $17.80^{\mathrm{b}}$ & $17.47^{\mathrm{c}}$ & $17.95^{\mathrm{b}}$ & $18.48^{\mathrm{a}}$ & 0.22 \\
Copper (mg/kg) & $0.60^{\mathrm{d}}$ & $0.71^{\mathrm{c}}$ & $0.65^{\mathrm{d}}$ & $0.77^{\mathrm{b}}$ & $0.86^{\mathrm{a}}$ & 0.03 \\
Zinc (mg/kg) & 5.48 & 5.73 & 5.68 & 5.86 & 5.96 & 0.70 \\
Manganese $(\mathrm{mg} / \mathrm{kg})$ & 1.67 & 1.84 & 1.76 & 1.89 & 1.93 & 0.26 \\
Chlorine (mg/kg) & $175.64^{\mathrm{d}}$ & $182.36^{\mathrm{c}}$ & $181.55^{\mathrm{c}}$ & $187.96^{\mathrm{b}}$ & $190.78^{\mathrm{a}}$ & 1.20
\end{tabular}

a,b,c,d: Means carrying different superscript in each row are significantly different ( $\mathrm{p}<0.05)$; SEM: standard error of mean; 6Pm: 60\% P. maximum; 3Pm3Lp: 30\% P. maximum $+30 \%$ L. purpureus; 4Pm2Lp: 40\% P. maximum + $20 \%$ L. purpureus; $4 \mathrm{Pm} 2 \mathrm{Sh}: 40 \%$ P. maximum $+20 \%$ S. hamata; $3 \mathrm{Pm} 3 \mathrm{Sh}: 30 \%$ P. maximum $+30 \%$ S. hamata .

Table3. Nutrient intake of West African Dwarf goat fed on varied grass-legume mixture pellets

\begin{tabular}{|c|c|c|c|c|c|c|}
\hline PARAMETER & 6Pm & 3Pm3Lp & 4Pm2Lp & 4Pm2Sh & 3Pm3Sh & SEM \\
\hline Mean DMI(g/animal/day) & $403.75^{\mathrm{e}}$ & $432.32^{b}$ & $425.36^{c}$ & $413.57^{d}$ & $458.75^{\mathrm{a}}$ & 2.74 \\
\hline Mean CPI (g/animal/day) & $64.79^{d}$ & $70.29^{b}$ & $70.22^{\mathrm{b}}$ & $67.60^{\mathrm{c}}$ & $76.72^{\mathrm{a}}$ & 1.02 \\
\hline Mean CFI (g/animal/day) & $59.82^{\mathrm{c}}$ & $57.85^{\mathrm{b}}$ & $58.65^{\mathrm{b}}$ & $57.51^{\mathrm{b}}$ & $62.81^{\mathrm{a}}$ & 1.10 \\
\hline Mean Ash (g/animal/day) & $28.79^{c}$ & $31.82^{\mathrm{b}}$ & $31.48^{\mathrm{b}}$ & $30.36^{\mathrm{b}}$ & $34.09^{\mathrm{a}}$ & 1.03 \\
\hline Mean DMI (\% of BW) & $4.25^{\mathrm{c}}$ & $4.64^{\mathrm{a}}$ & $4.40^{\mathrm{b}}$ & $4.27^{\mathrm{c}}$ & $4.32^{\mathrm{c}}$ & 0.13 \\
\hline
\end{tabular}

Table4. Growth indices of West African Dwarf goat fed on varied grass-legume mixture pellets

\begin{tabular}{lllllll}
\hline PARAMETER & 6Pm & 3Pm3Lp & 4Pm2Lp & 4Pm2Sh & 3Pm3Sh & SEM \\
\hline Number of Goats & 6 & 6 & 6 & 6 & 6 & \\
Duration(days) & 56 & 56 & 56 & 56 & 56 & \\
Initial weight(kg) & 7.57 & 7.56 & 7.57 & 7.57 & 7.57 & 0.11 \\
Final weight(kg) & $10.74^{\mathrm{b}}$ & $10.44^{\mathrm{b}}$ & $11.08^{\mathrm{a}}$ & $11.15^{\mathrm{a}}$ & $11.39^{\mathrm{a}}$ & 0.21 \\
Total Weight gain(kg) & $3.17^{\mathrm{c}}$ & $2.88^{\mathrm{d}}$ & $3.51^{\mathrm{b}}$ & $3.58^{\mathrm{b}}$ & $3.82^{\mathrm{a}}$ & 0.18 \\
ADG (g/animal/day) & $56.61^{\mathrm{c}}$ & $51.43^{\mathrm{d}}$ & $62.68^{\mathrm{b}}$ & $63.93^{\mathrm{b}}$ & $68.20^{\mathrm{a}}$ & 1.49 \\
Total FI (kgDM/animal) & $22.61^{\mathrm{b}}$ & $24.21^{\mathrm{ab}}$ & $23.82^{\mathrm{b}}$ & $23.16^{\mathrm{b}}$ & $25.69^{\mathrm{a}}$ & 1.36 \\
Feed consumed/ animal/ day & 0.403 & 0.432 & 0.425 & 0.414 & 0.459 & 0.024 \\
FCR & $7.13^{\mathrm{ab}}$ & $8.41^{\mathrm{a}}$ & $6.79^{\mathrm{b}}$ & $6.47^{\mathrm{b}}$ & $6.73^{\mathrm{b}}$ & 0.41 \\
PER & $0.84^{\mathrm{b}}$ & $0.71^{\mathrm{c}}$ & $0.86^{\mathrm{b}}$ & $0.88^{\mathrm{b}}$ & $0.91^{\mathrm{a}}$ & 0.02 \\
\hline
\end{tabular}

a,b,c,d: Means carrying different superscript in each row are significantly different ( $<<0.05)$; SEM: standard error of mean; 6Pm: 60\% P. maximum; 3Pm3Lp: 30\% P. maximum + 30\% L. purpureus; 4Pm2Lp: 40\% P. maximum + $20 \%$ L. purpureus; $4 \mathrm{Pm} 2 \mathrm{Sh}: 40 \%$ P. maximum $+20 \%$ S. hamata; $3 \mathrm{Pm} 3 \mathrm{Sh}: 30 \%$ P. maximum $+30 \%$ S. hamata .

Bio-economics indices of West African Dwarf goat fed on varied mixture of forage pellets are as shown in Table 5. Cost of feed $(\mathrm{N} / \mathrm{kg})$, consumed $(\mathrm{N})$, consumed/day/animal and feed/weight gain $(\mathrm{N} / \mathrm{kg})$ were highest $(\mathrm{p}<0.05)$ for 3Pm3Lp (N48.15/kg, N1,250.50 and N434.20/kg), respectively. 60\% Pellet from Panicum maximum (6Pm) had least values (N40.65/kg, N986.90, N17.63/animal/day and N22.33/animal/day and N311.32/kg), meanwhile 
cost of feed/weight gain was similar across the pellets except for 3Pm3Lp. Feed consumed was highest for 3Pm3Sh $(0.459 \mathrm{~kg} / \mathrm{animal} / \mathrm{day})$, however, it was similar to 3 Pm3Lp $(0.432 \mathrm{~kg} / \mathrm{animal} / \mathrm{day})$ while $0.403 \mathrm{~kg} / \mathrm{animal} / \mathrm{day}$ recorded for $6 \mathrm{Pm}$ was the least.

Table5. Bio-economics indices of West African Dwarf goat fed on varied mixture of forage pellets

\begin{tabular}{|c|c|c|c|c|c|c|}
\hline PARAMETER & 6Pm & 3Pm3Lp & 4Pm2Lp & 4Pm2Sh & 3Pm3Sh & SEM \\
\hline Cost of feed produced( $\# / k g)$ & $40.65^{\mathrm{c}}$ & $48.15^{\mathrm{a}}$ & $45.65^{\mathrm{b}}$ & $46.05^{\mathrm{b}}$ & $44.25^{\mathrm{b}}$ & 1.37 \\
\hline Feed consumed (kg/animal/day) & $0.403^{c}$ & $0.432^{\mathrm{ab}}$ & $0.425^{\mathrm{bc}}$ & $0.414^{\mathrm{bc}}$ & $0.459^{\mathrm{a}}$ & 0.24 \\
\hline Cost of feed consumed ( & $986.90^{\mathrm{d}}$ & $1250.50^{\mathrm{a}}$ & $1155.56^{\mathrm{c}}$ & $1146.18^{\mathrm{c}}$ & $1208.83^{b}$ & 11.66 \\
\hline $\begin{array}{l}\text { Cost of feed consumed } \\
(\$ / \text { animal/day) }\end{array}$ & $17.62^{\mathrm{c}}$ & $22.33^{\mathrm{a}}$ & $20.64^{b}$ & $20.47^{\mathrm{b}}$ & $21.59^{\mathrm{ab}}$ & 1.18 \\
\hline Cost of feed/Weight gain( $(\mathrm{N} / \mathrm{kg})$ & $311.32^{\mathrm{b}}$ & $434.20^{\mathrm{a}}$ & $329.22^{\mathrm{b}}$ & $320.16^{\mathrm{b}}$ & $316.45^{\mathrm{b}}$ & 13.67 \\
\hline
\end{tabular}

\subsection{Discussion}

The average dry matter (DM) content of the pellets in this study was higher than the value of $88.83 \%$ reported by Fasae (2014) for cassava-leaf pellets as dry season feed in smallholder sheep production and 89.1\% (Oyaniran et al., 2018) for pellets from forage legumes. The difference between this study and others could be traced to the types of forages used. The variation in crude protein $(\mathrm{CP})$ content of the pellets of this study could be attributed to the differences in the types of legume combined with the grass, inclusion levels, handling and processing. Crude protein increased with lager legume inclusion level in this study. This agrees with the report by Amole et al. (2012) which showed an increase in CP of forage-based pellets with increased legume inclusion. Also, the higher CP as compared to the calculated CP could be attributed to the nutrient synchrony as observed by Hersom (2008) and, Isah and Babayemi (2010). The observed range in this study was comparable with $17.50 \%$ recorded by Fasae (2014) but higher than 11.7\% (Oyaniran et al., 2018). The CP values were also higher than the recommended minimum requirement (7\%) for ruminant animals in the tropics (NRC, 1981, Humphreys, 1991) and 7.00\% $8.00 \%$ recommended for the efficient functioning of rumen microorganisms (Van Soest, 1994; Norton, 1994). They also exceeded the range of 11.00 to $13.00 \%$ known to be capable of supplying adequate protein for maintenance and moderate growth in goats (NRC, 1981). Therefore, this forage pellets could be a good source of feed for ruminant animals.

The extent at which rumen microflora degrade ingesta is a significant implications on forage intake and digestibility (Peterson et al., 1994). The neutral detergent fibre (NDF) and the acid detergent fibre (ADF) contents were higher than the observed values in a related study (Fasae, 2014) and this could be attributed to the type of forage, differences in processing techniques and the age of the forages at harvest. Roughage diets with NDF content of $40-65.5 \%$ and below $45 \%$ are generally considered as medium and high quality feeds, respectively (Singh and Oosting, 1992). Thus the NDF contents of the pellets in this study were within the range of medially rated feeds. High NDF values have been associated with decreased digestibility and hence, feed intake (Van Soest, 1994; McDonald et al., 1985). The higher percentage of NDF in a diet especially when energy is in deficit, affects the growth rate, feed intake efficiency and protein efficiency ratio which will result from dilution of their rations (Delorme et al., 1985). Reduction in fibre fractions for legume included pellets suggest increases feed intake as well as nutrient digestibility of the ingested diets, thus, these pellets will be of good nutritive quality to fed ruminants.

Akinsoyinu and Onwuka (1988) stated that mineral elements in animal feed play a vital role on the metabolic processes that cannot be overemphasized. Insignificant mineral contents in this present study negated the report of Minson (1988) who observed higher mineral contents in legume than grass. This could be averred to a synergy between the forages and the included fixed feed components. The calcium $(\mathrm{Ca})$ content fell within the range of $0.17-1.5 \%$ recommended for goats $(\mathrm{NRC}, 1981)$ while potassium $(\mathrm{K})$ content in the pellet diets was within the value of 26.5 - 33.4 g.kg-1 reported by Amole et al. (2013). This was however higher than NRC (1981) 
recommendation for lactating goats $(0.80 \%)$ and $0.50 \%$ recommended for maintenance requirement by nonlactating goats. The phosphorus content of the pellets was above the minimum of $0.15 \%$ recommended for ruminant $(\mathrm{NRC}, 1981)$ but agreed with recommended $(0.1-0.48 \mathrm{~g} / 100 \mathrm{~g})$ requirements for different classes of ruminant animals (McDowell, 1996; 1997). The variations observed for mineral compositions in this study as compared with other studies elsewhere could be due forage compositions, locality of the forage growth, species and age at harvest (Amole et al., 2013). Therefore, these pellets are adequate in supplying mineral contents needed by goats for both growth maintenance and production without supplementation.

Asaolu et al. (2012) observed that dry matter intake could be affected by crude protein intake levels while Oni et al. (2010) and Oduguwa et al. (2013) recorded that feed intake in ruminants is also influenced by a taste-related factor-palatability. Masafu (2006) made a description of feed intake as 'a measure of diet appreciation, selection and consumption by an animal.' The differences in the intake pattern of the animals within the pellets could be the reflection of the relative acceptability and palatability of these pellets. In view of feed intake as percentage of body weights, the intake values were within the recommendation for dry matter intake levels for small ruminants (NRC, 1985). The reports by Ajayi et al. (2005) and Ososanya (2010) revealed that feed intake as an important indicator for effective utilization of feed by livestock and 'a critical determinant of protein quality as well as performance in the small ruminant.' The increased consumption of 3Pm3Sh probably due to increased ruminal degradation rate of the pellets and rate of passage of digesta as a result of increased activity of cellulolytic of rumen flora (Van Soest, 1994) which could have been triggered by the significantly higher $(p<0.05) \mathrm{CP}$ in the diet. The reduction in the consumption rate of 6Pm compared with other pellets, though within recommended levels (NRC, 1985), could have resulted from a slight reduction in mineral and nitrogen contents (Leng, 1992; Given and Moses, 1995). Therefore, legume inclusion in the pellets increased their crude protein and as well the intake of the animals relatively to $6 \mathrm{Pm}$. The better feed conversion ratio (FCR) of the animals on legume included pellets except for $3 \mathrm{Pm} 3 \mathrm{Lp}$ and $6 \mathrm{Pm}$ in this study could be ascribed to their more efficient utilization by the animals as indicated by their lower feed conversion ratios, similar to the report of Tripathi et al. (2006) and Asaolu et al., (2012). The relative advantage of pellet $3 \mathrm{Pm} 3 \mathrm{Sh}$ over the pellet $4 \mathrm{Pm} 2 \mathrm{Sh}$ could furthermore be detected in the protein efficiency ratios (PER), probably attributable to the better quality of pellet 3Pm3Sh protein for ruminant nutrition. The lowest cost $/ \mathrm{kg}$ of $6 \mathrm{Pm}$, though not significant as compared to others except for $3 \mathrm{Pm} 3 \mathrm{Lp}$, was as a result of sole grass used in formulating the pellets. The highest $(\mathrm{p}<0.05)$ cost of production of feed/Weight gain observed in $3 \mathrm{Pm} 3 \mathrm{Lp}$ could be an indication that it is not economical for a modest production of WAD goats.

\section{Conclusion and Recommendation}

Pellet from 30\% Panicum maximum $+30 \%$ Stylosanthes hamata (3Pm3Sh) had a better chemical composition and influenced the performance of WAD goat. Cost of feed/weight gain was relative across the treatments except for $30 \%$ Panicum maximum $+30 \%$ Lablab purpureum (3Pm3Lp). Therefore, grass-legume pellets can be engaged as ruminant feed while pellet of $3 \mathrm{Pm} 3 \mathrm{Sh}$ is the best grass-legume combination for WAD goats, thus, they can serve as feed during the dry season.

\section{References}

Aderinola O. A., Akingbade A. A., Akinwumi, A. O. Ewetola, O. \& Adegorite, M. O. (2008). "Effect of Gliricidia sepium supplementation on intake, digestibility and nitrogen balance of WAD Sheep and Goats fed vetiver grass", Bowen Journal of Agricultue 5(1\&2), 80-86.

Aderinola O. A., Akinlade J. A., Akingbade A. A., Binuomote R. \& Alalade J. A. (2011). "Performance and Nutritional Composition of Andropogon tectorum during a Minor Wet Season as Influenced by Varying Levels of Inorganic Fertilizer", Journal of Agriculture, Forestry and Social Sciences 9(1), 129-142.

Ajayi, D. A., Adeneye, J. A. \& Ajayi, F. T. (2005). "Intake and Nutrient Utilization of West African Dwarf Goats Fed Mango (Mangifera indica), Ficus (Ficus thionningii), Gliricidia (Gliricidia sepium) Foliages and Concentrates as Supplement to Basal Diet of Guinea Grass (Panicum maximum)", World Journal of Agriculture Science 1(2), 184 - 189.

Ajayi, F. T. (2008). "Nutritional Evaluation of Guinea grass (Panicum maximum cv Ntchisi) Intercropped with Some Legumes for West African Dwarf Goats", Ph.D Thesis, University of Ibadan, Nigeria.

Akinsoyinu, A. O. \& Onwuka, C. F. I. (1988). "Mineral constituents of some browse plants used in ruminant feeding in southern Nigeria", Nigerian Journal of Animal Production 15, 57-62.

Amole T. A., Oduguwa B. O., Jolaosho, A. O., Shittu O., Arigbede, O. M. Olanite, J. A., Ojo V. O. A., Dele P. A. \& Idowu, O. J. (2012). "Nutrient Composition of Panicum maximum and Cowpea Haulms Pelleted at Diffrent Rations", Proc. $17^{\text {th }}$ Annual Conference Animal Science Association of Nigeria, 9-13, Abuja. 
Amole, T. A., Oduguwa, B., Shittu, O., Nkwelum, N., Dele, P. A., Ojo, V. O. A., Odeyemi, B., Toviesi, P. \& Famakinde, A. (2013). "Preference of Muturu Cattle to either Fresh Forage or Pelleted Hay of Panicum maximum and Pennisetum purpureum cut at Four and Eight Weeks", Slovak Journal of Animal Science 46(2), 68-74.

AOAC (2000). "Association of Official Analytical Chemists: Official Methods of Analysis", $6^{\text {th }}$ Edition. Washington DC, USA, 69-88.

ARC (1980). “Agricultural Research Council: The Nutrient Requirement of Ruminant Livestock Supplement, No 1, Commonwealth Agricultural Bureaux", Agronomy Journal 6(7), 571-574.

Asaolu, V., Binuomote, R., Akinlade, J., Aderinola, O. \& Oyelami, O, (2012). "Intake and Growth Performance of West African Dwarf Goats Fed Moringa oleifera, Gliricidia sepium and Leucaena leucocephala Dried Leaves as Supplements to Cassava Peels", Journal of Biology, Agriculture and Healthcare 2(10), 76-88.

Baudo, E. A. \& Hancock, J. D. (2003). "Pelleted Diets for Lactating Sows", Report of progress 920, Kansas State University, Manhatta, 33-35.

Conrad, H. R. (1966). Symposium on Factors Influencing the Voluntary Intake of Herbage by Ruminants: Physiological and Physical Factors Limiting Feed Intake". Journal of Animal Science 25, 227-235.

Delorme, C. B., Barrette, D., Mongeau, R. \& Lariviere, N. (1985). "The Effect of Dietary Fibre on Feed Intake and Growth in Beagle Puppies", Canadian Journal of Comp Medicine 49(3), 278-285.

Fasae, O. A. (2014). "Evaluation of Cassava Leaf Pellets as Dry Season Feed in Smallholder Sheep Production", Nigeria Journal Animal Science 16(1), 116-123.

Fritz, J. S. and Schenk, G. H. (1979). "Quantitative Analytical Chemistry”,. $4^{\text {th }}$ Edition, Allyn and Bacon, Inc., Boston, Massachusetts.

Given, D. I. \& Moses, A. R. (1995). “The Nutritional Value of Cereal Straw for Ruminants. A Review”, Nutrition Abstracts and Reviews (Series B) 65 (11), 793 - 811.

Hersom, M. J. (2008). "Opportunities to Enhance Performance and Efficiency through Nutrient Synchrony in Forage-Fed Ruminants”, Journal Animal Science, Apr;(14 Suppl), E306-17.

Humphrey, L. R. (1991). “Tropical pasture utilization”, Cambridge University Press, Cambridge, U. K. 202p.

Isah O. A. \& Babayemi O. J. (2010). "Nutrient Degradability and Performance by West African Dwarf Goats Fed Rumen Epithelium Based Diets”, Journal of Agricultural Science and Technology 12, 289-297.

Lebbie, S. H. B. (2004). "Goats under household conditions”, Small Ruminant Research 51, 131 - 136.

Leng, R. A. (1992). "Drought Feeding Strategies: Theory and Practice”, Penambul Books, Armidale, 162p.

Masafu, M. M. (2006). "The Evaluation of Leucaena leucocephala (Lam) DE WIT: A Renewable Protein Supplement for Low Quality Forages", PhD Thesis, University of South Africa.

McDonald P., Edwards R.A., Greenhalgh J. F. D. \& Morgan C. A. (1985). “Animal nutrition”, $6^{\text {th }}$ Edition, Prentice Hall, USA.

McDowell, L. R. (1996). "Feeding Minerals to Cattle on Pasture”, Animal Feed Science Technology 60, $247-271$.

McDowell, L. R. (1997). "Minerals for Grazing Ruminants in Tropical Regions", Extension Bulletin, Animal Science Department, Centre for Tropical Agriculture, University of Florida, 81.

Minson, D. J. (1990). "Forage in Ruminant Nutrition", Academic Press, New York, USA, 483p.

Norton, B. W. (1994). "The nutritive value of tree legumes", Available at http://www.fao.org/ag/AGP/AGPC/doc/Publicat/Gutt-shel/x5556e0j.htm., 1-10.

NRC (1981). National Research Council. "Nutrient Requirements of Goats: Angora, Dairy and Meat in Temperate and Tropical Countries", National Academies Press, Washington D. C., USA, ISBN-13:9780309031851, $91 \mathrm{p}$.

NRC (1985). National Research Council. "Nutrient Requirements of Sheep", 6th Revised Edition. National Academies Press, Washington D. C., USA.

Odeyinka, S. M. (2000). "Feeding behaviour and diet selection by West African Dwarf goats. Arch. Tierz., Dummerstorf 43 (1), $57-61$.

Odeyinka S. M \& Okunade G. K (2005). Goat Production in Oyo State: A Case Study of Ogbomoso Town”, Nigeria Journal Animal Production 32(1), 108-115.

Okoruwa, M. I. \& Adewumi, M. K. (2010). "Effect of Replacing Panicum maximum with Dried Pineapple Pulp on Nutrient Digestibility and Nitrogen Balance of West African Dwarf sheep", Nigeria Journal of Animal Science 32, 108-115.

Olaniyi J. O. (2006). "Influence of Nitrogen and Phosphorus Fertilizers on Seed Yield and Quality of Egusi Melon (Citrullus lanatus (Thunb) Mansf) in Ogbomoso, Southwestern Nigeria”, Ph.D Thesis, University of Ibadan, 155p. 
Oni, A. O., Arigbede, M. O., Oni, O. O., Onwuka, C. F. I., Anele, U. Y., Oduguwa, B. O. \& Yusuf, K. O. (2010). "Effect of Feeding Different Levels of Dried Cassava Leaves (Manihotesculenta, Crantz) Based Concentrates with Panicum maximum Basal on the Performance of Growing West African Dwarf Goats", Journal of Livestock Science 129, 24-30.

Oduguwa, B. O., Amole, T. A, Okwelum, N., Oni, A. O., Toviesi, P. D., Oderinwale, O. A. \& O. A. Soyomokun (2013). "Performance, Storability and Microbiological assay of Pelletized and Un-pelletized CassavaBased Diets Fed to Muturu Calves", African Journal of Agricultural Research 8(22), 2750-2756.

Ososanya, T. O. (2010). "Effect of Varying Levels of Broiler Litter on Growth Performance and Nutrient Digestibility of West African Dwarf Lambs", Nigeria Journal Animal Science 12, 123-128.

Oyadiran, D. K,. Ojo, V. O. A., Aderinboye, R. Y., Bakare, B. A. \& Olanite, J. A. (2018). "Effect of Pelleting on Nutritive of Forage Legumes", Livestock Research for Rural Development 30(4), 1-8.

Peterson, J. A., Belyea, L. A., Bowman, J. P., Kerley, M. S. \& Williams, J. E. (1994). "Forage Quality, Evaluation and Utilization”, in: Fahey, G. C. (ed). Amer. Soc. Agron. Madison, Wisconsin, USA. 59-107.

Singh, G. P. \& Oosting, S. J. (1992). “A Model for Describing the Energy Value of Straws”, Indian dairman XLI, 322-327.

Singh, M. K., Tripathi, M. K., Dixit, A. K. \& Singh, S. K. (2016). "Effect of Straw Type (Cajnus cajan or Cicer arietinum) and Form of Diet on Growth, Feed Efficiency and Slaughter Performance of Weaned Jamunapari Goat Kids", Indian Journal of Animal Science 86(3), 329-334.

SPSS, (2010). "Statistical Package of Social Science", Personal Computer Version 19.0, Michigan Avenue, Chicago Illinois, USA.

Tripathi, M. K., Karim, S., Chaturvedi, O. H. \& Singh, V. K. (2006). "Effect of ad libitum Tree Leaves Feeding with Varying Levels of Concentrate on Intake, Microbial Protein Yield and Growth of Lambs", Livestock Research for Rural Development 18, Article \#179. Retrieved November 22, 2011, from http://www.lrrd.org/lrrd18/12/trip18179.htm

Van Soest, P. J., Robertson, J. B. \& Lewis, B. A. (1991). "Methods for Dietary Fibre, Neutral Detergent Fibre and Non-starch Polysaccharides in Relation to Animal Nutrition", Journal of Dairy Science 74, 3579 - 3583.

Van Soest, P. J. (1994). "Nutritional Ecology of the Ruminant", Second edition, Comstock Publishing Associates; Cornell University Press, Ithaca and London. 476p. 